University of Nebraska - Lincoln

DigitalCommons@University of Nebraska - Lincoln

$1-1999$

\title{
Predation of Artificial Ground Nests on White-Tailed Prairie Dog Colonies
}

Bruce W. Baker

U.S. Geological Survey

Thomas R. Stanley

U.S. Geological Survey

James A. Sedgwick

U.S. Geological Survey

Follow this and additional works at: https://digitalcommons.unl.edu/usgsstaffpub

Part of the Earth Sciences Commons

Baker, Bruce W.; Stanley, Thomas R.; and Sedgwick, James A., "Predation of Artificial Ground Nests on White-Tailed Prairie Dog Colonies" (1999). USGS Staff -- Published Research. 51.

https://digitalcommons.unl.edu/usgsstaffpub/51

This Article is brought to you for free and open access by the US Geological Survey at DigitalCommons@University of Nebraska - Lincoln. It has been accepted for inclusion in USGS Staff -- Published Research by an authorized administrator of DigitalCommons@University of Nebraska - Lincoln. 


\section{allen press \\ PUBLISHING SERVICES}

Predation of Artificial Ground Nests on White-Tailed Prairie Dog Colonies

Author(s): Bruce W. Baker, Thomas R. Stanley, James A. Sedgwick

Source: The Journal of Wildlife Management, Vol. 63, No. 1 (Jan., 1999), pp. 270-277

Published by: Allen Press

Stable URL: http://www.jstor.org/stable/3802509

Accessed: 23/06/2009 00:36

Your use of the JSTOR archive indicates your acceptance of JSTOR's Terms and Conditions of Use, available at http://www.jstor.org/page/info/about/policies/terms.jsp. JSTOR's Terms and Conditions of Use provides, in part, that unless you have obtained prior permission, you may not download an entire issue of a journal or multiple copies of articles, and you may use content in the JSTOR archive only for your personal, non-commercial use.

Please contact the publisher regarding any further use of this work. Publisher contact information may be obtained at http://www.jstor.org/action/showPublisher?publisherCode=acg.

Each copy of any part of a JSTOR transmission must contain the same copyright notice that appears on the screen or printed page of such transmission.

JSTOR is a not-for-profit organization founded in 1995 to build trusted digital archives for scholarship. We work with the scholarly community to preserve their work and the materials they rely upon, and to build a common research platform that promotes the discovery and use of these resources. For more information about JSTOR, please contact support@ jstor.org. 


\title{
PREDATION OF ARTIFICIAL GROUND NESTS ON WHITE-TAILED PRAIRIE DOG COLONIES
}

\author{
BRUCE W. BAKER,' U.S. Geological Survey, Midcontinent Ecological Science Center, 4512 McMurry Avenue, Fort Collins, CO \\ 80525, USA \\ THOMAS R. STANLEY, U.S. Geological Survey, Midcontinent Ecological Science Center, 4512 McMurry Avenue, Fort Collins, \\ CO 80525, USA \\ JAMES A. SEDGWICK, U.S. Geological Survey, Midcontinent Ecological Science Center, 4512 McMurry Avenue, Fort Collins \\ CO 80525, USA
}

\begin{abstract}
Prairie dog (Cynomys spp.) colonies are unique to prairie and shrub-steppe landscapes. However, widespread eradication, habitat loss, and sylvatic plague (Yersinia pestis) have reduced their numbers by $98 \%$ since historical times. Birds associated with prairie dogs also are declining. Potential nest predators, such as coyotes (Canis latrans), swift foxes (Vulpes velox), and badgers (Taxidea taxus), may be attracted to colonies where a high concentration of prairie dogs serve as available prey. Increased abundance of small mammals, including prairie dogs, also may increase the risk of predation for birds nesting on colonies. Finally, because grazing by prairie dogs may decrease vegetation height and canopy cover, bird nests may be easier for predators to locate. In this study, we placed 1,444 artificial ground nests on and off 74 white-tailed prairie dog $(C$. leucurus) colonies to test the hypothesis that nest predation rates are higher on colonies than at nearby off sites (i.e., uncolonized habitat). We sampled colonies from 27 May to 16 July 1997 at the following 3 complexes: Coyote Basin, Utah and Colorado; Moxa Arch, Wyoming; and Shirley Basin, Wyoming. Differences in daily predation rates between colonies and paired off sites averaged 1.0\% ( $P=0.060)$. When converted to a typical 14-day incubation period, predation rates averaged $14 \%$ higher on colonies $(57.7 \pm 2.7 \% ; \bar{x} \pm \mathrm{SE})$ than at off sites $(50.4 \pm 3.1 \%)$. Comparisons of habitat variables on colonies to off sites showed percent canopy cover of vegetation was similar $(P=0.114)$, percent bare ground was higher on colonies $(P<0.001)$, Robel cover (i.e., visual obscurity of vegetation) was lower on colonies $(P<0.001)$, and density of active burrows was higher on colonies $(P<0.001)$. However, none of these habitat variables was correlated with differences in predation rates $(P>0.288)$. Although we found the risk of nest predation was higher on white-tailed prairie dog colonies than at off sites, fitness of birds nesting on colonies might depend on other factors that influence foraging success, reproductive success, or nestling survival.
\end{abstract}

JOURNAL OF WILDLIFE MANAGEMENT 63(1):270-277

Key words: artificial nests, Colorado, Cynomys leucurus, ground-nesting birds, predation, shortgrass prairie, shrub-steppe, Utah, vegetation, white-tailed prairie dog, Wyoming.

Prairie dogs have been described as a keystone species in western North America (Miller et al. 1994). Before European settlers altered the land, all 5 species of prairie dogs may have occupied 41 million ha (Anderson et al. 1986), but habitat loss from conversion of land to agriculture, direct poisoning of prairie dogs to reduce competition with livestock, and the spread of sylvatic plague have reduced their distribution by perhaps $98 \%$ (Marsh 1984). Avian species associated with prairie dogs also have declined, including a host of grassland and shrubsteppe birds (Knopf 1996). Many prairie birds, such as the mountain plover (Charadrius montanus), killdeer (Charadrius vociferus), horned lark (Eremophila alpestris), and McCown's

\footnotetext{
${ }^{1}$ E-mail: bruce_baker@usgs.gov
}

longspur (Calcarius mccownii) nest on the ground in prairie dog colonies.

Higher densities of predators on prairie dog colonies may place nests at a greater risk of predation. Krueger (1986) suggested the density of medium-sized predators, such as coyotes, swift foxes, and badgers, was 5.7 times higher on colonies than at off sites. Small mammals also are efficient predators of bird eggs (Cannings and Threlfall 1981) and can reach even higher numbers on colonies (Agnew et al. 1986). Deer mice (Peromyscus maniculatus) and northern grasshopper mice (Onychomys leucogaster) were nearly 3 times more abundant on colonies than at off sites in an Oklahoma study (O'Meilia et al. 1982). Another suggested nest predator is the prairie dog itself, although supporting data are lacking (Mickey 1943). Finally, avian nest 
predators may find nests on colonies easier to locate (Creighton and Porter 1974).

Nests on colonies may be easier for predators to locate because the vegetation is typically shorter and less dense. Prairie dogs remove vegetation through herbivory and, presumably, to increase visibility for predator detection (Clark 1977, Hoogland 1995). This contrast between a colony and its surrounding area creates edge, and edge can increase nest predation (Yahner 1996, Fenske-Crawford and Niemi 1997). For example, studies in fragmented tallgrass prairies (Burger et al. 1994) show higher predation rates near edges and in smaller fragments. In western shrub-steppe habitats, vegetation structure is an important predictor of predation rates for artificial sage grouse (Centrocercus urophasianus) nests (DeLong et al. 1995).

Our objective was to evaluate nest predation of ground-nesting birds on white-tailed prairie dog colonies. Specifically, we asked the following questions: (1) was nest predation higher on colonies than at nearby off sites?; (2) were differences in vegetative cover or prairie dog burrow density good predictors of differences in nest predation rates?; (3) how did type of disturbance to eggs and nests differ on and off colonies?; and (4) did evidence suggest prairie dogs may be nest predators? For this study, we used artificial nests to simulate natural nests of ground-nesting birds. We assumed differences in predation rates of artificial nests placed on and off colonies were a reasonably accurate index to differences in predation rates of natural nests (Major and Kendal 1996). Except where noted, we assumed nest disturbance was the result of attempted or successful nest predation.

\section{STUDY AREA}

White-tailed prairie dogs occur throughout the shrub-steppe and western shortgrass prairie ecosystems in the Rocky Mountain region (Fig. 1), although occupied habitat within this area varies greatly. In the east, low-growing shrubs and native grasses support McCown's longspurs, mountain plovers, and horned larks. In the west, Brewer's sparrows (Spizella breweri), sage sparrows (Amphispiza belli), and horned larks are common on or near prairie dog colonies.

To represent this variation and broaden our inferential ability, we selected our study colonies from 3 major complexes (a complex is an aggregation of colonies; Biggins et al. 1993) across the range of the white-tailed prairie dog

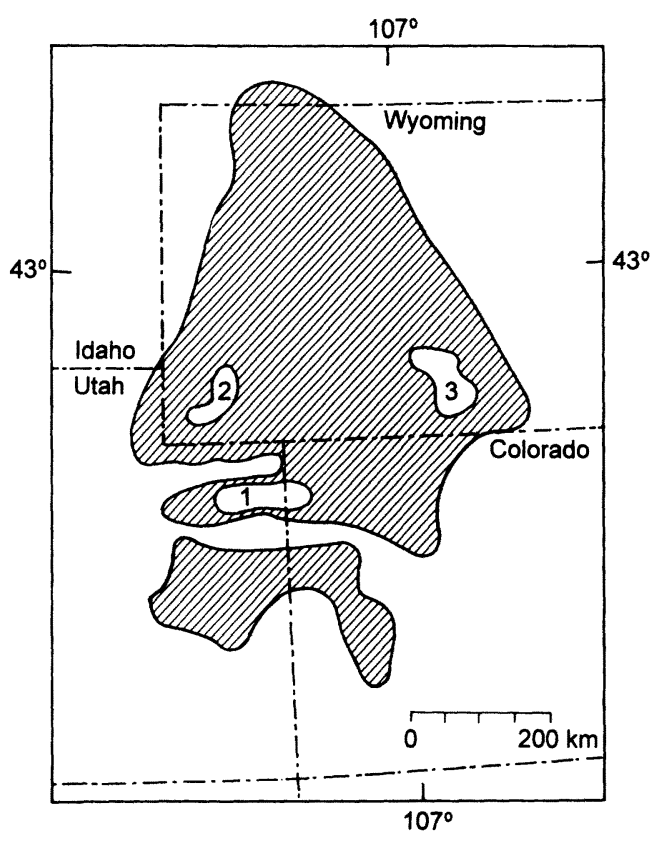

Fig. 1. Range of the white-tailed prairie dog based on Hall (1981), and complexes sampled ( 1 = Coyote Basin, sampled 27 May-18 Jun 1997; 2 = Moxa Arch, sampled 18-29 Jun 1997; 3 = Shirley Basin, sampled 30 Jun-16 Jul 1997).

(Fig. 1). Based on data from agency biologists, these 3 complexes also had the most recent and accurate colony location maps and contained the greatest number of large active colonies. Coyote Basin (Complex 1 in Fig. 1) was typical of the sagebrush-steppe of northeastern Utah and represented the extreme of brush-dominated white-tailed prairie dog habitat. Big sagebrush (Artemisia tridentata) and black greasewood (Sarcobatus vermiculatus) were the dominant overstory shrubs; exotic plants dominated the understory, especially cheatgrass (Bromus tectorum) and tumble mustard (Sisymbrium altissimum). This complex was planned as a future black-footed ferret (Mustela nigripes) reintroduction site. Moxa Arch (Complex 2 in Fig. 1) was a recently mapped complex and was within an active natural gas development field (Bureau of Land Management 1995). Colonies at Moxa Arch were smaller and more isolated. Habitat was typical of Wyoming Basin shrubsteppe: dominant plant species were low to moderate height shrubs such as Gardner saltbush (Atriplex gardneri) and big sagebrush. Common grasses were Sandberg bluegrass (Poa secunda) and Indian rice grass (Oryzopsis contracta). Shirley Basin (Complex 3 in Fig. 1) was a past black-footed ferret reintroduction site oc- 
curring in the transition between shortgrass prairie and shrub-steppe. Vegetation was dominated by very low-growing shrubs, such as birdsfoot sage (Artemisia pedatifida) and Gardner saltbush, and by a mostly native grass-forb component of intermediate wheatgrass (Agropyron intermedium), phlox (Phlox hoodii), and woody aster (Xylorhiza glabriuscula). All 3 complexes occurred primarily on land administered by the Bureau of Land Management, were grazed by livestock (primarily cattle), were open to recreational prairie dog shooting, and had sylvatic plague in the prairie dog population. Sampling periods were 27 May-18 June 1997 at Coyote Basin, 18-29 June 1997 at Moxa Arch, and 30 June-16 July 1997 at Shirley Ba$\sin$.

\section{METHODS}

\section{Experimental Design}

We sampled 74 prairie dog colonies (treatment replicate), using 1,444 artificial nests in a design that paired each colony with a nearby off site (control). To determine if habitat differences on and off colonies helped explain differences in predation rates, we estimated canopy cover, Robel cover (i.e., visual obscurity of vegetation; Robel et al. 1970), percent bare ground, and burrow density on each of the 74 colonies and their paired off sites. We also recorded type of nest disturbance for each predation event.

\section{Colony Selection}

Colonies were initially selected from maps prepared by agency biologists and sampled if they were a minimum size of approximately 500 $\times 1,000 \mathrm{~m}$, had prairie dogs present or fresh scat (i.e., greenish black in color) at burrows, and access permission was obtained. Agency biologists had mapped colonies before our study began, typically by walking or driving colony perimeters with a Global Positioning System or by using a combination of aerial photographs, topographic maps, and ground-truthing. All colonies at each complex were sampled if they met these criteria and a suitable off site could be located. Paired on and off sites typically had similar livestock grazing, soil type, and topography. To locate off sites, we looked at colony boundaries to observe the type of habitat prairie dogs were colonizing and then searched nearby (usually $0.5-2.0 \mathrm{~km}$ ) for similar sites lacking prairie dog colonies. Suitable off sites were sometimes difficult to find; if an off site could not be found, the colony was not sampled. Some off sites contained a few scattered prairie dog burrows.

\section{Vegetation-Burrow Density Data}

We measured vegetation and burrow density along a single transect line in each of the 74 selected colonies and their paired off sites. Transects averaged $1,400 \mathrm{~m}$ long (range $=800$ $2,400 \mathrm{~m}$ ). They began near the edge of a colony and continued through the center of prairie dog activity until the opposite side was reached (i.e., transect layout reflected colony shape and locations of active burrows). At off sites, we tried to mimic transect layout on paired colonies. We placed a pin flag every $100 \mathrm{~m}$ along transect lines and sampled vegetation with a Daubenmire plot (Mueller-Dombois and Ellenberg 1974) and Robel pole (Robel et al. 1970) placed $4 \mathrm{~m}$ from either side of the flag (2 plots and poles/flag). We recorded 4 readings (in $\mathrm{cm}$ from perpendicular locations) at each Robel pole location. On an average $1,400-\mathrm{m}$ transect line, this method yielded 30 Daubenmire plots and 120 Robel cover estimates. We used the Daubenmire scale, as modified by Bailey and Poulton (1968), to estimate percent canopy cover of shrubs, grasses, forbs, litter, and bare ground at each $20-\times 50-\mathrm{cm}$ plot (Mueller-Dombois and Ellenberg 1974). In the analysis, we combined canopy cover measures into 2 categories: percent bare ground and percent vegetation cover (shrubs + grasses + forbs + litter). We estimated Robel cover $(\mathrm{cm})$ by observing (from 1 $\mathrm{m}$ high and $4 \mathrm{~m}$ away) 1.5-m-tall Robel poles and recording the highest interval (marked in $2.5-\mathrm{cm}$ increments) completely obscured by vegetation. Burrow density was estimated by recording the number of active prairie dog burrows within $1.5 \mathrm{~m}$ of a transect line (Biggins et al. 1993).

\section{Nest Data}

We placed artificial nests $(\bar{x}=9.75$ nests/colony; $\bar{x}=9.75$ nests/off site) $100 \mathrm{~m}$ apart along vegetation transect lines to compare predation rates on and off colonies. To aid nest relocation, we recorded compass direction and distance (4$15 \mathrm{~m}$ ) from the transect line (marked with pin flags) to each nest location. We selected nest locations using a search image that represented likely nest sites for ground-nesting birds typical of the area (i.e., horned lark, McCown's longspur). This location was generally at the base of, 
or within, a shrub, grass, or forb clump (With 1994, Beason 1995). We used the same search image on colonies and paired off sites. We scraped a shallow depression at each nest site and placed a single, fresh Japanese quail $(\mathrm{Co}$ turnix japonica) egg in it. These eggs were slightly smaller than mountain plover or killdeer eggs but were larger than those of horned larks or sparrows.

We placed equal (or nearly equal) numbers of nests on and off a particular colony on the same day, which ensured comparable exposure to predation across treatments. After an exposure time of $t_{1}$ days, nests were checked to determine if they had been disturbed. If eggs were found intact and logistical constraints permitted, eggs were left in the nest for an additional $t_{2}$ days and checked again for predation.

We recorded the condition of the nest scrape and egg each time it was checked to compare type of nest disturbance on and off colonies. We used 4 categories to analyze type of disturbance: none, egg moved but still intact, egg gone, and egg broken or crushed. We did not attempt to identify specific nest predators based on appearance of eggshell fragments, believing this technique leads to misidentification problems (Baker 1978, Hernandez et al. 1997).

\section{Statistical Procedures}

We compared nest predation on and off the 74 colonies by calculating daily predation probabilities for each colony $\times$ site (on, off) combination and computing the difference in these probabilities for paired sites (i.e., $d=$ Prob $_{\text {on }}$ Prob $\left._{\text {off }}\right)$. A $t$-test of $\mathrm{H}_{\mathrm{o}}: \bar{d}=0$ versus $\mathrm{H}_{\mathrm{a}}: \bar{d}>$ 0 was computed for predation probability, differences in percent vegetation cover $\left(\mathrm{H}_{\mathrm{a}}: \bar{d}<\right.$ 0 ), differences in percent bare ground $\left(\mathrm{H}_{\mathrm{a}}: \bar{d}>\right.$ $0)$, differences in Robel cover $\left(\mathbf{H}_{\mathrm{a}}: \bar{d}<0\right)$, and differences in number of active prairie dog burrows per hectare $\left(\mathrm{H}_{\mathrm{a}}: \bar{d}>0\right)$. Because alternative hypotheses were specified a priori, we used 1-tailed tests. We used multiple regression to determine if measured habitat variables were good predictors of differences in predation rates. In this analysis, the difference in the daily predation probability was the dependent variable, and differences in percent vegetation cover, percent bare ground, Robel cover, and burrow density were the explanatory variables.

To calculate daily predation probabilities, we modeled the success or failure of a nest over an interval, $t$, as an independent Bernoulli trial with parameter $\pi_{t}$. We then reparameterized $\pi_{t}$ in terms of the daily survival probability to obtain the probability a nest succeeds or fails over $t$ days:

$$
P(Y=y \mid p)=\left(p^{t}\right)^{y}\left(1-p^{t}\right)^{1-y},
$$

where $y=1$ if the nest succeeds, $y=0$ if the nest is depredated, and $p$ is the daily survival probability of the nest. Assuming that for the $i$ th colony $(i=1, \ldots, 74)$ daily survival probabilities for the on $\left(p_{i}\right)$ and off $\left(c_{i}\right)$ sites are homogeneous (i.e., colony $\times$ site combinations are homogeneous), the likelihood function for the data is proportional to

$$
\prod_{i=1}^{74} \prod_{t}\left(p_{i}^{t}\right)^{s_{i t}}\left(1-p_{i}^{t}\right)^{f_{i t}}\left(c_{i}^{t}\right)^{s^{\prime} i t}\left(1-c_{i}^{t}\right)^{f^{\prime} i t},
$$

where, for given $i$ and $t, s$ is the number of successful nests at the on site and $s^{\prime}$ is the number of successful nests at the off site, and $f$ is the number of disturbed nests at the on site and $f^{\prime}$ is the number of disturbed nests at the off site. Estimators for $p_{i}, c_{i}$, and their variances were derived via standard maximum likelihood methods (Larsen and Marx 1986) and, for a given colony $\times$ site combination, are equivalent to the estimators in Johnson (1979). Because closed-form solutions for these estimators do not exist, we used Newton's method to solve for the parameters (Swokowski 1988). Daily predation probabilities for on sites were computed as $1-p_{i}$, and daily predation probabilities for off sites were computed as $1-c_{i}$.

We also investigated various submodels of the colony $\times$ site model in Equation (1) by constraining parameters to obtain simpler models. In particular, we imposed the constraint $p_{i}=c_{i}$, which assumes daily survival probabilities within a colony and its paired off site do not differ and constrained parameters so that daily survival probabilities within a complex $\times$ site combination were homogeneous. According to Akaike's Information Criterion (AIC; Akaike 1973), the general model (1), which retains separate parameters for each colony $\times$ site combination (i.e., $p_{1}, \ldots, p_{74}, c_{1}, \ldots, c_{74}$ ), was the most parsimonious model and should be used for parameter estimation (AIC $=2,651.1$ ). This result is in agreement with likelihood-ratio tests, which rejected a submodel constraining $p_{i}=c_{i}$ $\left(\chi_{67}^{2}=136.4, P<0.001 ;\right.$ AIC $\left.=2,659.1\right)$ and rejected the second model constraining colonies within a particular complex $\times$ site combination 
Table 1. On colony and off-site comparisons of type of disturbance to 1,444 artificial nests at 74 white-tailed prairie dog colonies in Colorado, Utah, and Wyoming, 1997.

\begin{tabular}{lcrr}
\hline \multicolumn{1}{c}{ Type of disturbance } & On & Off & Total \\
\hline None & 337 & 393 & 730 \\
$\begin{array}{l}\text { Egg moved from nest but still } \\
\text { intact }\end{array}$ & 111 & 78 & 189 \\
$\begin{array}{l}\text { Egg gone without sign of } \\
\text { disturbance }\end{array}$ & 163 & 158 & 321 \\
$\begin{array}{l}\text { Egg broken or crushed, shell } \\
\quad \text { fragments in or near nest }\end{array}$ & 111 & 93 & 204 \\
Total & 722 & 722 & 1,444 \\
\hline
\end{tabular}

to have homogeneous nest survival probabilities $\left(\chi^{2}{ }_{136}=357.0, P<0.001 ;\right.$ AIC $\left.=2,718.9\right)$.

\section{RESULTS}

We summarized disturbance type for all 1,444 artificial nests and found eggs unmoved and intact at 730 nests $(51 \%)$, moved but intact at 189 nests $(13 \%)$, gone without sign of disturbance at 321 nests $(22 \%)$, and broken or crushed at 204 nests (14\%; Table 1). For purposes of estimating daily survival probabilities, nests with eggs unmoved and intact (730) were considered undisturbed (success; $s$ or $s^{\prime}$ in Eq. 1), and all other nests (714) were considered disturbed (failure; $f$ or $f^{\prime}$ in Eq. 1). The resulting daily survival probability estimates were used to test for differences in predation rates between on and off sites and were used to compute 14day predation rates $(\%)$ to mimic an incubation period typical of grassland and shrub-steppe birds.

Differences in daily predation rates between on and off sites averaged $1.0 \pm 0.6 \%(\bar{x} \pm \mathrm{SE}$; $\left.t_{73}=1.57, P=0.060\right)$. When converted to 14 day rates, nest predation averaged $14 \%$ higher on colonies $(\bar{x}=57.7 \pm 2.7 \%)$ than at off sites $(\bar{x}=50.4 \pm 3.1 \%)$. For vegetation and burrow density data, we found mean differences were $-3.1 \pm 2.5 \%\left(t_{73}=-1.21, P=0.114\right)$ for vegetation cover, $6.0 \pm 1.9 \%\left(t_{73}=3.09, P<\right.$ $0.001)$ for bare ground, $-3.0 \pm 0.6 \mathrm{~cm}\left(t_{73}=\right.$ -4.66, $P<0.001$ ) for Robel cover, and $94.2 \pm$ 6.2 burrows/ha $\left(t_{72}=15.27, P<0.001\right)$ for density of active prairie dog burrows. There was less available nesting cover and more prairie dogs on colonies than at nearby off sites. These patterns were generally consistent across all 3 complexes (Table 2). Interestingly, the difference in mean 14-day nest predation was greatest (12.7\%) at the Moxa Arch complex in southwestern Wyoming, where vegetation cover was the lowest and bare ground the highest both on and off colonies. However, regression analysis showed that none of the 4 explanatory variables we tested was useful as a predictor of differences in nest predation rates on and off colonies ( $P$ s $>0.288$ for all variables).

Eggs were moved from the nest (often about $15 \mathrm{~cm}$ ) but still intact at 111 nests on colonies and 78 nests at off sites (Table 1). These data suggest moved but intact eggs strongly influenced our finding that nest predation was higher on colonies. Because nesting birds may not recognize or incubate an egg moved from their nest, the usual method in nest predation studies is to consider these nests as disturbed. In our study, however, we believed prairie dogs may have moved eggs without trying to eat them, possibly a result of curiosity about something

Table 2. On colony and off-site comparisons of 14-day nest predation rates and habitat variables at 3 white-tailed prairie dog complexes in Colorado, Utah, and Wyoming, 1997.

\begin{tabular}{|c|c|c|c|c|c|c|c|}
\hline \multirow[b]{3}{*}{ Variable } & \multirow[b]{3}{*}{ Site } & \multicolumn{6}{|c|}{ Complex } \\
\hline & & \multicolumn{2}{|c|}{ Coyote Basin $\left(n^{\mathrm{a}}=31\right)$} & \multicolumn{2}{|c|}{ Moxa Arch $(n=9)$} & \multicolumn{2}{|c|}{ Shirley Basin $(n=34)$} \\
\hline & & $\bar{x}$ & $\mathrm{SE}$ & $\overline{\bar{x}}$ & $\mathrm{SE}$ & $\bar{x}$ & $\mathrm{SE}$ \\
\hline \multirow{4}{*}{$\begin{array}{l}\text { 14-day nest predation } \\
(\%)^{\mathrm{b}} \\
\text { Vegetative cover }(\%)\end{array}$} & On & 47.7 & 4.1 & 60.7 & 9.6 & 66.0 & 3.2 \\
\hline & Off & 42.6 & 4.7 & 48.0 & 12.2 & 58.0 & 3.7 \\
\hline & On & 59.2 & 4.2 & 34.4 & 3.7 & 56.4 & 1.6 \\
\hline & Off & 59.2 & 3.6 & 39.8 & 3.9 & 60.8 & 2.8 \\
\hline \multirow[t]{2}{*}{ Bare ground $(\%)$} & On & 50.6 & 2.9 & 77.3 & 2.1 & 48.2 & 2.2 \\
\hline & Off & 45.6 & 2.5 & 65.9 & 3.3 & 43.3 & 2.4 \\
\hline \multirow[t]{2}{*}{ Robel cover $(\mathrm{cm})$} & On & 3.3 & 0.5 & 1.5 & 0.3 & 0.4 & 0.1 \\
\hline & Off & 9.3 & 1.8 & 2.7 & 0.4 & 1.4 & 0.4 \\
\hline \multirow{2}{*}{$\begin{array}{l}\text { Active burrows } \\
\text { (burrows/ha) }\end{array}$} & On & 76.1 & 7.2 & 98.5 & 18.7 & 116.1 & 9.2 \\
\hline & Off & 0.2 & 0.1 & 1.4 & 1.4 & 0.7 & 0.3 \\
\hline
\end{tabular}

a $n=$ number of colonies sampled.

${ }^{\mathrm{h}}$ Calculated from daily survival probabilities. 
new to their territory. Because this response may not have occurred with natural nests, we reanalyzed the data by combining the 189 moved but intact nests with the 730 survived nests and considered these 919 nests as undisturbed (success; $s$ or $s^{\prime}$ in Eq. 1). Using these categories, we found that nest predation did not differ between on and off sites $(d=0.2 \pm 0.5 \%$; $\left.t_{73}=0.34, P=0.369\right)$. Mean 14-day predation rates were $44.8 \pm 2.7 \%$ at colonies and $41.6 \pm$ $3.0 \%$ at off sites.

\section{DISCUSSION \\ Prairie Dogs as Nest Predators}

Prairie dogs have been reported as potential nest predators, but without supporting data (Mickey 1943, With 1994). Prairie dogs might reasonably be assumed to prey on bird eggs because thirteen-lined ground squirrels (Spermophilus tridecemlineatus) and related species are known nest predators (With 1994) and because prairie dogs scavenge animal carcasses and cannibalize their young (Hoogland 1995). However, if prairie dogs regularly eat bird eggs, then nest predation should be much higher on colonies, even higher than the $7 \%$ difference we observed. Mean prairie dog density at our $3 \mathrm{com}$ plexes was about $7.1 / \mathrm{ha}$ on colonies and $0.5 / \mathrm{ha}$ at off sites (no. of prairie dogs $=0.073 \times$ number of active burrows; Biggins et al. 1993), suggesting eggs on colonies were at high risk of detection by prairie dogs. Even eggs placed near active burrows often were not damaged, indicating at least some prairie dogs ignored eggs they clearly must have found. We did find more nests with eggs moved but intact on colonies (Table 1), suggesting prairie dogs may have at least been curious about eggs in their territory. However, these moved but intact eggs also may have been unsuccessful predation attempts by other small mammals (e.g., deer mice), which also may be more abundant on colonies (Agnew et al. 1986). However, without predator identification data, conclusions drawn from circumstantial evidence in our study could be incorrect. Research that identifies predators at nests is clearly needed before we implicate prairie dogs as nest predators.

\section{Nest Predation Differences}

A variety of potential nest predators could have been responsible for the increase in predation rates we observed on colonies. Krueger (1986) reported that badgers and coyotes were more abundant on than off black-tailed prairie $\operatorname{dog}$ (C. ludovicianus) colonies. We observed both of these predators, as well as swift foxes, striped skunks (Mephitis mephitis), and longtailed weasels (Mustela frenata) on or near colonies at our study sites. However, we found similar numbers of eggs missing and broken on and off colonies (Table 1), which are the 2 most likely methods of egg destruction by these predators (Baker 1978, Hernandez et al. 1997). These data suggest the relative importance of medium-sized mammalian nest predators may have been similar on and off colonies. Deer mice and grasshopper mice, both potential nest predators at our colonies, also were more abundant on than off colonies at Badlands National Park in South Dakota (Agnew et al. 1986). These and other small mammals may have been responsible for some of the differential predation, or attempted predation (i.e., moved but intact eggs), we observed on and off colonies.

We also expected vegetation height and density to influence nest predation. Because Robel cover blends both metrics into 1 measure (Robel et al. 1970), it is often a good predictor of nesting habitat for grassland birds. At our study sites, we found that Robel cover was lower on colonies, but that it was not a good predictor of predation differences in the multiple regression analysis. However, the magnitude of the difference was small, as cover averaged only $3 \mathrm{~cm}$ less on colonies than at off sites. Perhaps this small difference was not meaningful to nest predators. Robel cover also may be a better predictor of nest predation for black-tailed prairie dogs, where the contrast on and off colonies is greater than for white-tailed prairie dogs (Hoogland 1995). In addition, livestock grazing may minimize differences between colonies and nearby off sites, regardless of the prairie dog species in question.

\section{Compensation for Higher Nest Predation on Colonies}

Even a $14 \%$ increase in 14-day predation rates, as we observed in our study, would likely suppress recruitment of birds into the local population. But why would birds nest on prairie dog colonies if the risk of nest predation is higher? We offer the following thoughts as speculation. Coevolution of nesting birds and prairie dogs occurred when colonies and complexes were much larger, and before fragmentation diminished their relative area. Perhaps before col- 
onies were fragmented, the risk of predation was not higher for birds nesting on colonies. However, recent fragmentation of prairie dog complexes into smaller and smaller colonies may have created "predator patches," unique features of the landscape that stand out from the surrounding matrix and create conditions that increase local predation rates. Colonies that function as predator patches may increase predator density (potentially increasing both primary and secondary nest predation) and allow predators to develop a more narrow and successful search image. In effect, fragmentation of prairie dog habitat may function similar to fragmentation of waterfowl nesting habitat in the Prairie Pothole Region, where nest predation rates of about $70 \%$ may limit waterfowl production (Greenwood et al. 1995). Fragmentation may be more important for black-tailed prairie dogs, where habitat loss on private lands has been severe. In contrast, white-tailed prairie dogs occur mostly on public rangelands, where control efforts have been less and the landscape still resembles historical conditions.

Under current conditions, species that evolved close associations with prairie dogs might compensate for increased predation by having increased relative fitness, perhaps through foraging efficiency or fledgling survival. Many birds associated with prairie dogs forage by walking on the ground, picking up insects or vegetative material as they move (e.g., McCown's longspur [With 1994], horned lark [Beason 1995]). At the Shirley Basin complex, we observed flocks of up to 40 juvenile horned larks foraging on colonies in this manner. Because there is less vegetation and more bare ground, foraging also may be more efficient on colonies than off (e.g., mountain plover; Olson 1985). In addition, insect species important to foraging birds may be more numerous on colonies (Olson 1985). Even if nest predation is significantly higher on colonies than surrounding habitat, the implications to fitness of local bird populations is uncertain. Clearly, more research is needed, especially on the interaction of avian fitness with spatial patterns of prairie dog abundance.

\section{MANAGEMENT IMPLICATIONS}

Many species associated with prairie dogs are declining in concert with the continued decline of prairie dogs. However, these associates have evolved to prefer nesting conditions on colo- nies. Therefore, any effect of slightly higher nest predation on colonies likely would not be a serious concern for managers, at least for white-tailed prairie dogs; however, the implications for other species are unclear. Because of habitat and behavioral differences, our results may not apply to the other 4 species of prairie dogs. We recommend further research on those species and their associated avifauna, especially where prairie dog control, habitat loss, or sylvatic plague threatens to further fragment remaining complexes. We also recommend further research on the role of prairie dogs as nest predators.

\section{ACKNOWLEDGMENTS}

We are very grateful to the following field assistants: T. R. Bosse, A. Boyle, J. R. Brooks, L. S. Comita, H. C. Ducharme, K. S. Kump, L. M. Locke, R. Scott, C. P. Smith, and M. Ward. Personnel from the Vernal, Utah, Kemmerer, Wyoming, and Rawlins, Wyoming, offices of the Bureau of Land Management, Dinosaur National Monument, Utah, and the Lander, Wyoming, office of the Wyoming Game and Fish Department provided logistical and technical support. We are especially grateful to B. Luce, T. C. Love, and W. Stroh for their help in locating prairie dog study colonies. F. L. Knopf and D. E. Biggins offered valuable insight about prairie dog ecosystems. We are grateful to $\mathrm{P}$. Chapman of Colorado State University for guidance concerning experimental design and statistical analysis. E. C. Hellgren, D. H. Johnson, G. Plumb, and R. Yahner provided valuable review comments on an earlier draft of the manuscript. This study was initiated through the U.S. Department of the Interior research needs process and was funded by the U.S. Geological Survey, Fort Collins, Colorado.

\section{LITERATURE CITED}

Agnew, W., D. W. URESK, AND R. M. HANSEN. 1986. Flora and fauna associated with prairie dog colonies and adjacent ungrazed mixed-grass prairie in western South Dakota. Journal of Range Management 39:135-139.

AKAIKE, H. 1973. Information theory as an extension of the maximum likelihood principle. International Symposium on Information Theory 2:267-281.

Anderson, E., S. C. Forrest, T. W. Clark, and L. RiChARDSON. 1986. Paleobiology, biogeography, and systematics of the black-footed ferret, Mustela nigripes (Audubon and Bachman), 1851. Great Basin Naturalist Memoirs 8:11-62.

Bailey, A. W., and C. E. Poulton. 1968. Plant com- 
munities and environmental relationships in a portion of the Tillamook Burn, northwestern Oregon. Ecology 49:1-13.

BAKER, B. W. 1978. Ecological factors affecting wild turkey nest predation on South Texas rangelands. Proceedings of the Annual Conference of the Southeastern Association of Fish and Wildlife Agencies 32:126-136.

BEASON, R. C. 1995. Horned lark (Eremophila alpestris). The Birds of North America, number 195. The American Ornithologists' Union, Washington, D.C., USA, and The Academy of Natura Sciences, Philadelphia, Pennsylvania, USA.

Biggins, D. E., B. J. Miller, L. R. Hanebury, B. OAKLEAF, A. H. FARMER, AND R. CRETE. 1993 A technique for evaluating black-footed ferret habitat. Pages 73-88 in J. L. Oldemeyer, D. E. Biggins, and B. J. Miller, editors. Proceedings of the symposium on the management of prairie dog complexes for the reintroduction of the blackfooted ferret. U.S. Fish and Wildlife Service Biological Report 13.

Bureau of Land Management. 1995. Surveys of prairie dog colonies, sage grouse leks, raptor nests, and federally-listed species. Expanded Moxa Arch Area, Natural Gas Development Project, Sweetwater, Lincoln, and Uinta Counties, Wyoming. U.S. Department of the Interior, Bureau of Land Management, Wyoming State Office, Cheyenne, Wyoming, USA

Burger, L. D., L. W. Burger, and J. FAABorg. 1994. Effects of prairie fragmentation on artificial nests. Journal of Wildlife Management 58:249254.

Cannings, R. J., and W. Threlfall. 1981. Horned lark breeding biology at Cape St. Marys, Newfoundland, Canada. Wilson Bulletin 93:519-530.

Clark, T. W. 1977. Ecology and ethology of the white-tailed prairie dog (Cynomys leucurus). Milwaukee Public Museum Publications in Biology and Geology 3.

Creighton, P. D., And D. K. Porter. 1974. Nest predation and interference by western meadowlarks. Auk 91:177-178.

Delong, A. K., J. A. Crawford, and D. C. DELONG. 1995. Relationships between vegetational structure and predation of artificial sage grouse nests. Journal of Wildlife Management 59:88-92.

FEnske-Crawford, T. J., AND G. J. NiEmi. 1997. Predation of artificial ground nests at two types of edges in a forest-dominated landscape. Condor 99:14-24.

Greenwood, R. J., A. B. Sargeant, D. H. Johnson, L. M. Cowardin, and T. L. ShafFer. 1995. Factors associated with duck nest success in the Prairie Pothole Region of Canada. Wildlife Monographs 128.

Hall, E. R. 1981. The mammals of North America. Volume 1. Second edition. John Wiley \& Sons, New York, New York, USA

Hernandez, F., D. Rollins, and R. Cantu. 1997. Evaluating evidence to identify ground-nest pred- ators in West Texas. Wildlife Society Bulletin 25 826-831.

Hoogland, J. L. 1995. The black-tailed prairie dog: social life of a burrowing mammal. University of Chicago Press, Chicago, Illinois, USA.

Johnson, D. H. 1979. Estimating nest success: the Mayfield method and an alternative. Auk 96:651661

KNOPF, F. L. 1996. Prairie legacies-birds. Pages 135-148 in F. B. Samson and F. L. Knopf, editors. Prairie conservation: preserving North America's most endangered ecosystem. Island Press, Washington, D.C., USA.

KrUEger, K. 1986. Feeding relationships among bison, pronghorn, and prairie dogs: an experimental analysis. Ecology 67:760-770.

LARSEN, R. J., AND M. L. MARX. 1986. An introduction to mathematical statistics and its applications. Second edition. Prentice-Hall, Englewood Cliffs, New Jersey, USA.

MajoR, R. E., AND C. E. KENDAL. 1996. The contribution of artificial nest experiments to understanding avian nest success: a review of methods and conclusions. Ibis 138:298-307.

MARSH, R. E. 1984. Ground squirrels, prairie dogs, and marmots as pests on rangeland. Pages 19.5208 in Proceedings of the conference for the organization and practice of vertebrate pest control, Hampshire, United Kingdom

MICKEY, F. W. 1943. Breeding habits of McCown's longspurs. Auk 60:181-209.

Miller, B., G. Ceballos, AND R. Reading. 1994 The prairie dog and biotic diversity. Conservation Biology 8:677-681.

Mueller-Dombois, D., AND H. EllenberG. 1974 Aims and methods of vegetation ecology. John Wiley \& Sons, New York, New York, USA.

OLSON, S. L. 1985. Mountain plover food items on and adjacent to a prairie dog town. Prairie Naturalist 17:83-90.

O'Meilia, M. E., F. L. KNopf, and J. C. Lewis. 1982. Some consequences of competition between prairie dogs and beef cattle. Journal of Range Management 35:580-585.

Robel, R. J., J. N. Briggs, A. D. DaYton, AND L. C. Hulbert. 1970. Relationships between visual obstruction measurements and weight of grassland vegetation. Journal of Range Management 23:295-297.

Swokowski, E. W. 1988. Calculus with analytic geometry. Fourth edition. PWS-Kent Publishing, Boston, Massachusetts, USA.

With, K. A. 1994. McCown's longspur (Calcarius mccownii). The Birds of North America, number 96. The American Ornithologists' Union, Washington, D.C., USA, and The Academy of Natural Sciences, Philadelphia, Pennsylvania, USA

YAHNER, R. H. 1996. Forest fragmentation, artificial nest studies, and predator abundance. Conservation Biology 10:672-673.

Received 16 March 1998.

Accepted 16 June 1998.

Associate Editor: Hellgren. 